\title{
Economic Value of Irrigation Water: Evidence from a Punjab Canal
}

\author{
Ijaz Hussain*, Maqbool H. Sial ${ }^{* *}$, Zakir Hussain ${ }^{* * * *}$, and \\ Waqar Akram
}

\begin{abstract}
This study is based on data from a cross sectional survey of 120 farms located along the Mithaluck irrigation canal in central Punjab. The data collected were analyzed using (i) the residual imputation method, and (ii) the change in net income method, and applied to a linear programming model to estimate the value productivity of irrigation water. Returns to irrigation varied by farm size and location on the canal, but were generally found to be very high relative to the estimated delivery cost of irrigation water. The results of this study could prove useful in determining the economic feasibility of various resources for supplementing water and improving delivery and application efficiencies.
\end{abstract}

JEL Classification: A10, C20.

Keywords: Irrigation, value of water, residual imputation, Punjab, Pakistan.

\section{Introduction}

Pakistan's water resources include local rainfall, surface water from the Indus River and its tributaries, and extensive groundwater resources in the deep alluvial deposits of the Indus Plain. While irrigation has been utilized for thousands of years, the modern use of irrigation on the Indus River began in the middle of the nineteenth century. Subsequently, an intricate network of water control and distribution developed into one of the largest irrigation systems in the world. Most of Pakistan's agricultural production is carried out in the Indus Basin and draws on this extensive irrigation network, which comprises some 40,000 miles of conveyance channels (i.e., canals, branches, distributaries, and minor channels) and 112 principal canal systems spanning more than 100,000 watercourses. In

${ }^{*},{ }^{* *},{ }^{* * *},{ }^{* * *}$ Department of Economics, University of Sargodha, Pakistan. 
addition, some 380 miles of large link canals have been constructed to connect the Indus River's tributaries. The combined diversion from the main canal system is nearly 114 billion cubic meters (bcm) (Government of Pakistan 2006). The total area served by the irrigation system within the Indus Plain amounts to 16.8 million ha. About 10.5 million ha of this area have perennial water supplies while the remainder receives only seasonal supplies, usually between mid-April and mid-October (Government of Pakistan 2006).

The strongest argument for not treating water as one might any other economic commodity is that its shortage does not determine its value. Water productivity is low in water-scarce countries or parts thereof, with the exception of rich economies that do not depend on agriculture. In Yemen for instance-one of the world's poorest countries in terms of water resources-water productivity and the performance of irrigation are among the lowest in the world. The same applies to poor regions of countries such as Jordan and the oases south of Egypt, as well as Tunisia, Algeria, Morocco, and Pakistan. In fact, water productivity seems to be lowest in the waterscarce regions of agriculture-based economies. Subsistence farmers bear the cost of water, such as pumping groundwater, to a certain extent. With the rising price of water, more and more "layers" of the poor are excluded, giving increasingly more of the nonpoor access to this resource. Thus, increasing the price of water is equivalent to creating inequities that favor the nonpoor/head farmers and discriminate against the poor/tail-end users.

The benefits of an irrigation system depend on the rules that govern it. For most of the twentieth century, water managers and engineers focused on building irrigation hardware, letting the development of rules ("software") lag behind. Flaws in an irrigation system's software design are easy to find. Large subsidies for irrigation are nearly universal, for instance: farmers receiving water from public projects rarely pay more than $20 \%$ of the real cost incurred and often far less. Less than $10 \%$ of the total recurring cost of large and medium irrigation projects built in the 1970s have been recovered in the Indus Basin (Postel 1999). Farmers in Tunisia, a country severely short of water, pay 5 cents per cubic meter for irrigation water-one seventh of what it costs to supply it. Irrigators in Jordan, one of the most water-strapped countries in the world, pay less than 3 cents per cubic meter, which is a small fraction of the water's total cost. According to one estimate, irrigation subsidies worldwide amount to USD33 billion per year. If the full costs of environmental damage, human resettlement from dam sites, and increased waterborne diseases from irrigation projects were to be factored in, the total subsidy tally would be much higher (Ahmad 2001). 
Along with massive subsidies, another major disincentive to efficiency is the absence of accountability for how an irrigation system actually performs-a problem that is especially serious in developing countries. Irrigation fees, although low, often go to the national treasury rather than into funds earmarked for operating and maintaining the system. As a result, the fees that farmers pay often have no bearing on the upkeep and performance of their irrigation networks. The failure of governments and international donors to design institutions and rules that might ensure the efficiency, equity, and sustainability of irrigation systems has left a large unfinished agenda in irrigated agriculture. The most important consideration is institutional design, i.e., the process of framing a set of rules and regulations that irrigators understand, agree on, and are willing to follow.

The economic valuation of any water allocation policy depends on estimates of the economic value of water-a measure of the net economic contribution of water to the value of agricultural production. Empirical estimates of the value of irrigation water also provide important evidence of farmers' ability to pay for implementing cost recovery programs. Another increasingly important use of irrigation water valuations arises in connection with the analysis of economic tradeoffs among water-using sectors. Although many agricultural uses of water yield high economic returns, the lowest valued consumptive uses of water are typically located in the production of agricultural crops (Young 1995).

Estimates of the economic value of irrigation water are often erroneous because the valuation of irrigation water is more difficult and complex than is commonly recognized. Errors in estimates usually overstate than understate. The principal source of overstatement is crediting water with returns that should be allocated to other inputs, such as labor and, particularly, human capital (Young 1995).

Water scarcity looms large in the Indus Basin. Of the total canal diversion, nearly $35 \mathrm{bcm}$ are consumed by crop production while $40 \%$ of water diverted from the river system is lost while being conveyed from the canal head to farm gates (Government of Pakistan 2006). This limited water supply suggests the importance of estimating the economic value of water to evaluate both structural and nonstructural methods of enhancing returns to a scarce resource. The marginal value product measures the incremental gains from the resource use, and can be compared with incremental cost to determine economic feasibility. Estimates of water resource productivity also provide a useful method for examining the efficiencies of the existing resource allocation, and aid in formulating national and provincial resource development policies. In Pakistan, however, there are no reliable estimates 
of the economic value of water. Farmers are charged a flat rate which hardly covers the cost of operation and maintenance (O\&M). Above all, the irrigation system is neutral in terms of allocation. Estimating the value of water is thus imperative for providing useful information to irrigation managers and policymakers.

While previous studies have tended to use secondary data and lacked empirical content, this study is based on survey data for an Indus River distributary, which adds empirical rigor. Moreover, the study focuses on the position (head or tail) of farmers served by the distributary. Unlike earlier studies, the objective here is to estimate the economic value of water, using both (i) the residual imputation method, and (ii) change in net income (CINI) method to evaluate water charges. The study also simulates different scarcity scenarios, which previous studies have not done. Estimating the economic value of water is cumbersome because water is not a traded input. Accurate estimates of its economic value have important policy implications.

\section{Data and Methodology}

A sample of 120 farmers was used to collect information on the farm budgets of various crops. The data included but was not limited to the cost of all inputs, price of output, yield, and water applications. Of the total sample, subsamples of 30 farmers each were used to represent small, large, and head- and tail-enders on the Mithaluck distributary in Sargodha. A farm budget for crops and farm level was developed to carry out a partial budget and economic analysis for each category of farmer. The same farm budget was used to construct a linear programming (LP) matrix to evaluate four models, namely, (i) small, (ii) large, (iii) head, and (iv) tail farms. Labor and water inputs were taken for a full crop calendar of 12 months to evaluate various scenarios. The two approaches used to estimate the economic value of water used are discussed below.

\subsection{Residual Imputation Approach}

The "residual" method is most commonly applied to shadow pricing irrigation water and other producers' goods. Broadly, it determines the contribution of each input to output in the production process. If appropriate prices can be assigned-presumably by market forces-to all production inputs but one, the remaining total value of product is imputed to the remaining or residual resource (Heady 1952). 


\section{Derivation}

The derivation requires two principle postulates. First, a well-known requirement of competitive equilibrium is that the prices of all resources are equated to returns at the margin (for each resource $i, P_{i}=V M P_{i}$ ). Profitmaximizing producers are assumed to add productive inputs to the point that value marginal products are equal to the opportunity cost of the inputs.

The second postulate requires that the total value of product be divisible into shares so that each resource is paid according to its marginal productivity and the total value of product is thereby completely exhausted. According to Euler's Theorem, the total value of product will be exactly exhausted by the distributive shares, but only in the event that its function is homogeneous in the first degree (Heady 1952, Debertin 1986). We shall assume that these postulates adequately represent actual agricultural production conditions.

Now consider an agricultural production process in which a single product denoted $\mathrm{Y}$ is produced by four factors of production: capital $(\mathrm{K})$, labor (L), natural resources, such as land (R), and irrigation water (W).

$$
\mathrm{Y}=\mathrm{f}(\mathrm{K}, \mathrm{L}, \mathrm{R}, \mathrm{W})
$$

We may write by the second postulate:

$$
\mathrm{TVP}_{\mathrm{Y}}=\left(\mathrm{VMP}_{\mathrm{k}} \mathrm{Q}_{\mathrm{k}}\right)+\left(\mathrm{VMP}_{\mathrm{L}} \mathrm{Q}_{\mathrm{L}}\right)+\left(\mathrm{VMP}_{\mathrm{R}} \mathrm{Q}_{\mathrm{R}}\right)+\left(\mathrm{VMP}_{\mathrm{W}} \mathrm{Q}_{\mathrm{W}}\right)
$$

Where TVP represents total value of product $\mathrm{Y}, \mathrm{VMP}$ represents value marginal product of resource $i$, and $Q$ is the quantity of resource $i$.

If competitive factor and product markets can be assumed, prices can be treated as known constants. The first postulate (which asserts that $\mathrm{VMP}_{\mathrm{i}}=\mathrm{P}_{\mathrm{i}}$ ) permits substituting into (2) and by rearranging:

$\operatorname{TVP}_{\mathrm{Y}}-\mathrm{P}_{\mathrm{k}} \mathrm{Q}_{\mathrm{k}}+\mathrm{P}_{\mathrm{L}} \mathrm{Q}_{\mathrm{L}}+\mathrm{P}_{\mathrm{R}} \mathrm{Q}_{\mathrm{R}}=\mathrm{P}_{\mathrm{W}} \mathrm{Q}_{\mathrm{W}}$

Assuming that all variables in (1) are known except $P_{w}$, the expression can be solved for that unknown to impute the shadow price of water $\mathrm{P}_{\mathrm{W}}^{*}$ as follows:

$$
\mathrm{P}_{\mathrm{w}}^{*}=\left(\mathrm{TVP}_{\mathrm{Y}}-\mathrm{P}_{\mathrm{K}} \mathrm{Q}_{\mathrm{K}}+\mathrm{P}_{\mathrm{L}} \mathrm{Q}_{\mathrm{L}}+\mathrm{P}_{\mathrm{R}} \mathrm{Q}_{\mathrm{R}}\right) / \mathrm{Q}_{\mathrm{w}}
$$

Equation (2) can, of course, be generalized to encompass cases in which input categories are further disaggregated. For example, capital (K) 
can be divided into various classes of durable or nondurable factors, or labor (L) into field and managerial work.

\section{Potential Problems in the Application of the Residual Method}

The assumptions underlying residual imputation are not overly restrictive, but care is required to assure that the conditions of production under study are reasonable approximations of the conceptual model. The main issues can be divided into two types: (i) those relating to the specification of the production function, and (ii) those relating to the market and policy environment, i.e., the pricing of outputs and nonresidual inputs (Young 1985). Problems include specifying the production function, assigning prices to inputs and outputs: measuring and pricing inputs and output, and the case of costing nondurable capital, durable capital, 1abor, and human effort. Another opportunity for overestimating returns to water is the proportion of acreage devoted to high-value crops in the long term. Some economists contend that, in most cases, any specialty crop production that occurs on a new irrigation project is likely to have merely displaced production elsewhere in the country.

\subsection{LP Mode1}

\section{CINI Method}

The additional income from a crop or farm was defined as the difference between net incomes "with" or "without" irrigation improvement models (small, large, head, and tail) developed on the Mithaluck distributary in the Indus Basin. This demonstrates the "with or without" principle for irrigation improvement and derivation of water charges (CINI).

In practical applications, irrigation water is often valued using the CINI method. The willingness to pay for an increment in water is the net producer's income associated with that increment. A process similar to that used for residual imputation can represent this approach. It is designed to accommodate the case of a multi-product firm in addition to the individual crop model discussed above. written as

A more general multi-crop/multi-input production function can be

$$
\mathrm{f}\left(\mathrm{Y}_{1}, \ldots \ldots . . \mathrm{Y}_{\mathrm{m}} ; \mathrm{X}_{1}, \ldots \ldots . \mathrm{X}_{\mathrm{n}}\right)=0
$$


Where $\mathrm{Y}$ is a vector of outputs for feasible crops and $\mathrm{X}$ a vector of production inputs. The net income $(\mathrm{Z})$ from producing a given set of crops can be represented by

$$
\mathrm{Z}=\sum_{\mathrm{i}=1 \ldots \mathrm{m}}\left(\mathrm{Y}_{\mathrm{i}} \mathrm{P}_{\mathrm{yi}}\right)-\sum_{\mathrm{j}=1 \ldots \mathrm{n}}\left(\mathrm{X}_{\mathrm{j}} \mathrm{P}_{\mathrm{xj}}\right)
$$

The CINI is

$$
\Delta \mathrm{Z}=\mathrm{Z}_{1}-\mathrm{Z}_{0}
$$

Where the subscripts 0 and 1 refer to the "without project" and "with project" situations, respectively.

Note that if land is the only residual claimant in the net income expression (6) (as it would be if the "without project" situation involved rain-fed cropping), then (6) is reduced to the residual imputation formula given in (4) above. In other words, $\mathrm{Z}_{0}$ represents the opportunity cost of the residual claimant, land in the "without project" situation.

\section{Results and Discussion}

\subsection{Residual Imputation Method}

The residual imputation method described as above was applied to estimate the economic value of water for all four farm categories as shown in Table-1 (see the appendix to this article for a detailed budget analysis).

Table 1: Economic Value of Irrigation Water by Crop and Farm Category, Mithaluck Distributary, Sargodha

\begin{tabular}{lcccc}
\hline Crops & $\begin{array}{c}\text { Small Farms } \\
\left(\mathbf{R s} / \mathbf{m}^{3}\right)\end{array}$ & $\begin{array}{c}\text { Large Farms } \\
\left(\mathbf{R s} / \mathbf{m}^{3}\right)\end{array}$ & $\begin{array}{c}\text { Head Farms } \\
\left(\mathbf{R s} / \mathbf{m}^{3}\right)\end{array}$ & $\begin{array}{c}\text { Tail Farms } \\
\left(\mathbf{R s} / \mathbf{m}^{3}\right)\end{array}$ \\
\hline Cotton & 2.32 & 3.49 & 2.71 & 1.87 \\
Maize & 1.13 & 1.17 & 0.51 & 0.98 \\
Rice & 1.30 & 1.17 & 0.76 & 1.39 \\
Sugarcane & 0.91 & 1.95 & 0.50 & 0.80 \\
Wheat & 1.51 & 0.90 & 0.70 & 1.06 \\
Citrus & 1.65 & 1.41 & 1.13 & 1.09 \\
\hline
\end{tabular}

The analysis reveals that the economic value of water for all crops is very high and that current water rates-Rs0.004 per cubic meter for rabi (winter) crops and Rs0.006 per cubic meter of kharif (summer) crops 
(Government of Punjab 2005)—fall far below its scarcity value. This shows that irrigation water is undervalued, leading to the inefficient use of a vital resource. The results of the study are consistent with Ahmad (2001), where the economic value of water is estimated at Rs121 per acre inch for wheat, Rs 57 for rice, Rs 26 for cotton, and Rs66 for sugar cane. The estimated marginal value product (MVP) of water is Rs148-226, i.e., many times higher than current water rates (kharif, Rs85, and rabi, Rs50). As indicated in the previous section, water charges evaluated at opportunity cost (sale of tube-well water at Rs100/acre inch) can safely be increased by $20 \%$ without a significantly negative effect on the objective function of the models estimated.

First, water prices cannot, for instance, be feasibly increased to the point where they start to affect water use and demand. Second, low water prices are frequently not the reason for water-intensive and inefficient crop choices. Thus, there is need to enforce allocation rules on existing canals which could in turn induce farmers to use less water and lead to a scarcity value reflecting its proper use.

The above analysis showed that estimated water charges are much higher than actual charges. This calls for a corrective policy measure by increasing water charges to an appropriate level in each of the above scenarios. The Government of Pakistan has either been providing subsidized irrigation water or deferring maintenance: neither case augurs well. Subsidies encourage the misallocation of water and become a burden on the exchequer of a resource-poor country, while deferred maintenance deteriorates the irrigation system much faster.

\subsection{CINI Method}

The CINI method can be adapted to mathematical programming models (the LP model) of farm situations to approximate a functional relationship between net benefits and irrigation water use (Burt 1964, Bowen and Young 1985, Chaudhry and Young 1989).

The programming model of a representative farm situation was formulated to maximize the net return to the residual claimant (the water resource in this case) subject to constraints on water availability. The model is solved for each of a number of increments in water supply and the net return to each increment of water derived from the incremental change in the objective function. The derivation of the marginal value product of water is shown through LP models.

The value of irrigation water can be derived through shadow prices in an LP model where water is the most constrained input. The basic 
concept for establishing shadow prices is the notion of willingness to pay as an indicator of value. Willingness to pay reflects a consumer's willingness to forego other consumption rather than do without the commodity in question. In accordance with the postulates of diminishing marginal productivity or utility, willingness to pay falls as increasing quantities are utilized. The measure of willingness to pay indicated by conventional wisdom is commensurate with market value and is an indication of exchange value. The technique for determining shadow prices (for an un-priced input, in this case irrigation water) is called the "residual imputation." This has already been discussed above. An extension of this procedure, the CINI method applied to an LP model, provides a useful tool for deriving the CINI for further derivation of the value of water.

Table-2: Economic Value of Water on Small Farms (CINI) on Mithaluck Distributary, Sargodha

\begin{tabular}{|c|c|c|c|c|c|}
\hline Model & $\begin{array}{c}\text { Irrigation } \\
\text { Water } \\
\left(\mathrm{m}^{3} / \text { acre }\right) \\
\end{array}$ & $\begin{array}{l}\text { Farm Net } \\
\text { Income (Rs) }\end{array}$ & $\begin{array}{c}\Delta \text { in } \\
\text { Irrigation } \\
\left(\mathbf{m}^{3)}\right.\end{array}$ & $\begin{array}{c}\Delta \text { in Net } \\
\text { Income (Rs) }\end{array}$ & $\begin{array}{c}\Delta \text { Net Income } / \Delta \\
\text { Irrigation } \\
\left(\mathrm{m}^{3}\right)\end{array}$ \\
\hline $\begin{array}{l}\text { Original } \\
\text { farm model }\end{array}$ & $23,952.20$ & $35,152.9$ & - & - & - \\
\hline $\begin{array}{l}10 \% \text { water } \\
\text { discount }\end{array}$ & $21,556.98$ & $27,419.3$ & $2,395.22$ & $7,733.6$ & 3.23 \\
\hline $\begin{array}{l}20 \% \text { water } \\
\text { discount }\end{array}$ & $19,401.28$ & $20,948.3$ & $2,155.70$ & $6,471.0$ & 3.00 \\
\hline $\begin{array}{l}30 \% \text { water } \\
\text { discount }\end{array}$ & $17,461.15$ & $15,816.0$ & $1,940.13$ & $5,132.3$ & 2.65 \\
\hline $\begin{array}{l}40 \% \text { water } \\
\text { discount }\end{array}$ & $15,715.04$ & $11,703.8$ & $1,746.12$ & $4,112.2$ & 2.36 \\
\hline $\begin{array}{l}50 \% \text { water } \\
\text { discount }\end{array}$ & $14,143.53$ & $8,660.8$ & $1,571.50$ & $3,043.0$ & 1.94 \\
\hline $\begin{array}{l}60 \% \text { water } \\
\text { discount }\end{array}$ & $12,729.18$ & $6,322.4$ & $1,414.35$ & $2,338.4$ & 1.65 \\
\hline
\end{tabular}


Figure 1: Economic Value of Water on Small farm at Mitha Luck Distributory

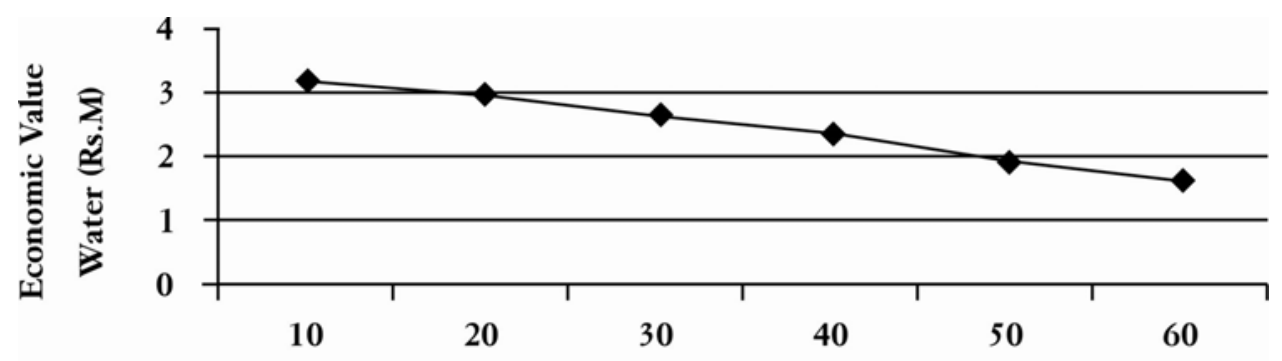

Water Discount (Percent)

Figure 2: Economic Value of Irrigation water on large farm at MItha Luck Distributory

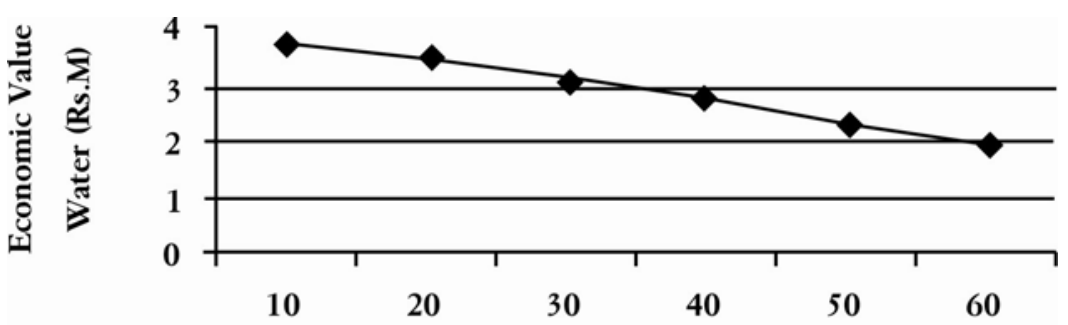

Water Discount (Percent)

\subsection{Model Results}

The model results obtained are given in Tables 2 to 5 . The results reveal that the economic value of water at discounted water availability varies from Rs1.63 to Rs3.23 per cubic meter on a small farm. The economic value of water was Rs1.63 per cubic meter even at a $60 \%$ water discount. In the case of large farms, the value varied from Rs1.93 to Rs3.76 per cubic meter for various discount scenarios; even under conditions of extreme stress, the economic value of water was Rs1.93 per cubic meter. In the case of head farms, the value varied from Rs1.03 to Rs2.01 per cubic meter, and from Rs1.39 to Rs2.74 per cubic meter at tail-end farms. Figure 1 shows the declining trend of the economic value of water per cubic meter under different water scarcity scenarios. It is interesting to note that, even under conditions of extreme scarcity and water stress, farms maintain their paying capacity. The economic value of water determined using both methods was almost the same. Thus, Indus farmers have the capacity to pay for irrigation water, the value of which can be increased manifold based on the economic value of water. 
In summary, the economic value of water varies between Rs1 and Rs3 per cubic meter both for individual crops and farm categories. The allocative efficiency criteria for the irrigation input warrants that the MVP of water must be equal to its price (opportunity cost) for efficient utilization. In the present case, the economic value of water or MVP of irrigation is much higher than its market price (opportunity cost). The existing water charges are Rs 50 per acre for rabi crops and Rs85 per acre for kharif crops-both charges are extremely low and hardly cover the cost of O\&M of irrigation. The consumptive use of sugarcane is nearly 5,500 cubic meters and that of wheat, 1,800 cubic meters. On the basis of consumptive use, the economic value of sugarcane is estimated at Rs5,000-6,000 per acre; that of wheat, Rs2,000-2,700 per acre. Comparing current water charges with the economic value of water for both crops showed that water charges can be increased manifold to recover O\&M costs. The Punjab government's Irrigation Department has a budgeted expenditure of Rs16 billion, of which $44 \%$ is current expenditure and 56\%, development costs (Government of Punjab 2005). Of the $44 \%$ of current expenditure, only $30 \%$ was spent on O\&M, implying that the current flat rate per season hardly covers maintenance costs. Even the revenue collected through water charges goes to the government treasury and is not targeted to canal maintenance. Keeping in view the scarcity of water and deterioration of the irrigation system, the government needs to consider a paradigm shift to bring about institutional changes in managing the canal system. Engineering solutions to water do not serve the purpose. Therefore, canal management should include agronomic, economic, and social consideration in allocating water. Water charges should reflect the scarcity of irrigation water. 
Table-3: Economic Value of Water on Large Farms (CINI) on Mithaluck Distributary, Sargodha

\begin{tabular}{lccccc}
\hline Model & $\begin{array}{c}\text { Irrigation } \\
\text { Water } \\
\left(\mathbf{m}^{3} / \mathbf{a c r e}\right)\end{array}$ & $\begin{array}{c}\text { Farm Net } \\
\text { Income } \\
(\mathbf{R s})\end{array}$ & $\begin{array}{c}\Delta \text { in } \\
\text { Irrigation } \\
\left(\mathbf{m}^{3)}\right.\end{array}$ & $\begin{array}{c}\Delta \text { in Net } \\
\text { Income } \\
(\mathbf{R s})\end{array}$ & $\begin{array}{c}\Delta \text { Net Income/ } \\
\text { Irrigation } \\
\left(\mathbf{m}^{3}\right)\end{array}$ \\
\hline Original farm mode1 & $3,0685.50$ & $52,444.1$ & - & - & - \\
10\% water discount & $27,616.95$ & $40,906.4$ & $3,068.55$ & $11,537.7$ & 3.76 \\
20\% water discount & $24,855.26$ & $31,252.5$ & $2,761.70$ & $9,653.9$ & 3.50 \\
30\% water discount & $22,369.73$ & $23,595.6$ & $2,485.53$ & $7,656.9$ & 3.08 \\
40\% water discount & $20,132.76$ & $17,460.8$ & $2,236.97$ & $6,134.9$ & 2.74 \\
50\% water discount & $18,119.48$ & $12,921.0$ & $2,013.28$ & $4,539.8$ & 2.25 \\
60\% water discount & $16,307.53$ & $9,432.3$ & $1,811.95$ & $3,488.7$ & 1.93 \\
\hline
\end{tabular}

Figure 3: Economic value of Water of Head farm at Mitha Luck Distributory

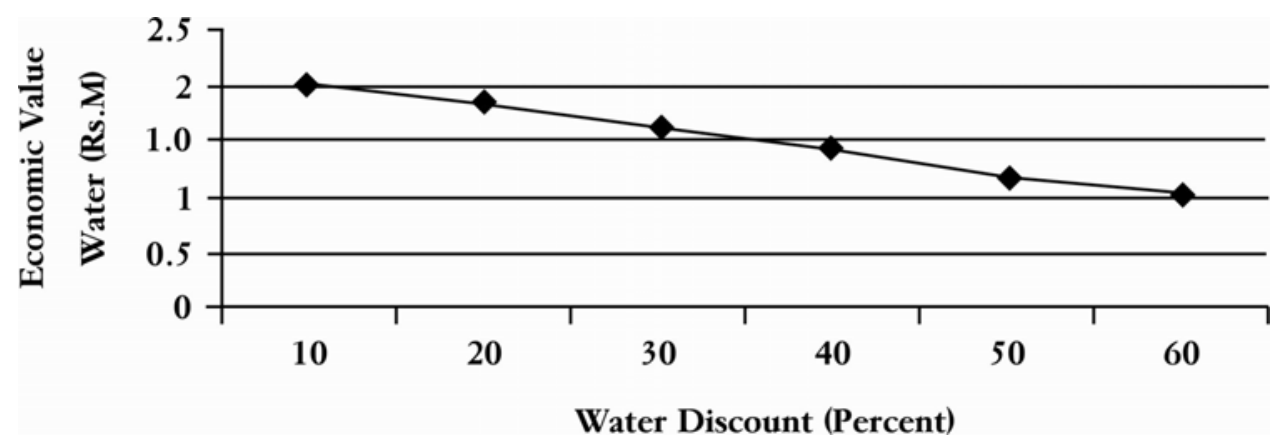

Figure 4: Economic Value of Water of Tail farm at Mitha Luck Distributory

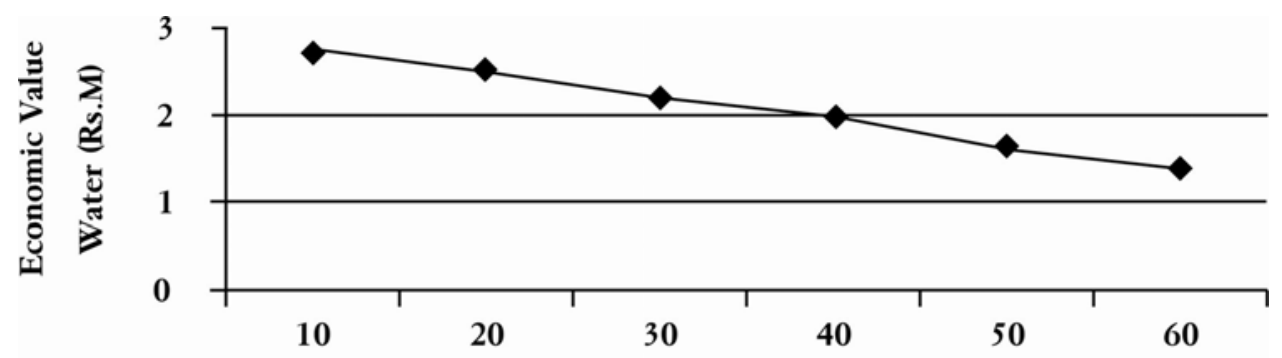

Water Discount (Percent) 
Table-4: Economic Value of Water on Head Farms (CINI) at Mithaluck Distributary, Sargodha

\begin{tabular}{lccccc}
\hline Model & $\begin{array}{c}\text { Irrigation } \\
\text { Water } \\
\left(\mathbf{m}^{3} / \text { acre }\right)\end{array}$ & $\begin{array}{c}\text { Farm Net } \\
\text { Income } \\
(\mathbf{R s})\end{array}$ & $\begin{array}{c}\Delta \text { in } \\
\text { Irrigation } \\
\left(\mathbf{m}^{3}\right)\end{array}$ & $\begin{array}{c}\Delta \text { in Net } \\
\text { Income (Rs) }\end{array}$ & $\begin{array}{c}\Delta \text { Net Income/ } \\
\text { Irrigation } \\
\left(\mathbf{m}^{3}\right)\end{array}$ \\
\hline $\begin{array}{l}\text { Original farm } \\
\text { mode1 }\end{array}$ & $32,620.50$ & $29,756.9$ & - & - & - \\
$\begin{array}{l}10 \% \text { water } \\
\text { discount }\end{array}$ & $29,358.45$ & $23,210.4$ & $3,262.05$ & $6,546.5$ & 2.01 \\
$\begin{array}{l}\text { 20\% water } \\
\text { discount }\end{array}$ & $26,422.61$ & $17,732.8$ & $2,935.85$ & $5,477.7$ & 1.87 \\
$\begin{array}{l}\text { 30\% water } \\
\text { discount }\end{array}$ & $23,780.34$ & $13,388.2$ & $2,642.26$ & $4,344.5$ & 1.64 \\
$\begin{array}{l}\text { 40\% water } \\
\text { discount }\end{array}$ & $21,402.31$ & $9,907.3$ & $2,378.03$ & $3,480.9$ & 1.46 \\
$\begin{array}{l}\text { 50\% water } \\
\text { discount }\end{array}$ & $19,262.08$ & $7,331.4$ & $2,140.23$ & $2,575.9$ & 1.20 \\
$\begin{array}{l}\text { 60\% water } \\
\text { discount }\end{array}$ & $17,335.87$ & $5,351.9$ & $1,926.21$ & $1,979.5$ & 1.03 \\
\hline
\end{tabular}

Table-5: Economic Value of Water on Tail farm (CINI) at Mitha Luck Distributory, Sargodha

\begin{tabular}{lccccc}
\hline Model & $\begin{array}{c}\text { Irrigation } \\
\text { Water } \\
\left(\mathbf{m}^{3} / \text { acre }\right)\end{array}$ & $\begin{array}{c}\text { Farm Net } \\
\text { Income } \\
(\mathbf{R s})\end{array}$ & $\begin{array}{c}\Delta \text { in } \\
\text { Irrigation } \\
\left(\mathbf{m}^{3)}\right.\end{array}$ & $\begin{array}{c}\Delta \text { in Net } \\
\text { Income (Rs) }\end{array}$ & $\begin{array}{c}\Delta \text { Net Income/ } \\
\text { Irrigation } \\
\left(\mathbf{m}^{3}\right)\end{array}$ \\
\hline $\begin{array}{l}\text { Original farm } \\
\text { mode1 }\end{array}$ & $20,772.00$ & $25,551.5$ & - & - & - \\
$\begin{array}{l}\text { 10\% water } \\
\text { discount }\end{array}$ & $18,694.80$ & $19,930.2$ & $2,077.20$ & $5,621.3$ & 2.71 \\
$\begin{array}{l}\text { 20\% water } \\
\text { discount }\end{array}$ & $16,825.32$ & $15,226.6$ & $1,869.48$ & $4,703.5$ & 2.52 \\
$\begin{array}{l}30 \% \text { water } \\
\text { discount }\end{array}$ & $15,142.79$ & $11,496.1$ & $1,682.53$ & $3,730.5$ & 2.22 \\
$\begin{array}{l}\text { 40\% water } \\
\text { discount }\end{array}$ & $13,628.51$ & $8,507.1$ & $1,514.28$ & $2,989.0$ & 1.97 \\
$\begin{array}{l}50 \% \text { water } \\
\text { discount }\end{array}$ & $12,265.66$ & $6,295.3$ & $1,362.85$ & $2,211.9$ & 1.62 \\
$\begin{array}{l}\text { 60\% water } \\
\text { discount }\end{array}$ & $11,039.09$ & $4,595.5$ & $1,226.57$ & $1,699.7$ & 1.39 \\
\hline
\end{tabular}




\section{Conclusions and Recommendations}

The study's most striking finding is that, on most farms, the economic value of water is very high relative to incremental cost. The results, both by crop and farm category, show that farmers have paying capacity even under high stress conditions. The highest value attributed to water was on large and head farms. Estimates of the economic value of water show that there is more than enough room to increase water charges to cover O\&M costs and reflect resource scarcity.

The engineering approach to canal management has outlived its utility, and irrigators must be assigned the task of managing this vital resource. Once irrigators are persuaded that they will be ensured a supply of water, they will be more than willing to pay on the basis of the MVP of water. Water allocation rules need to be revisited and made demand-driven while phasing out supply-oriented approaches to water delivery. Policymakers should focus on irrigation agronomy and look for soft rather hard solutions in order to efficiently manage this key resource. 


\section{References}

Ahmad, M. 2001, Water Pricing and Markets in the Near East, Policy Issues and Options. FAO Regional Office for the Near East, Cairo Egypt.

Bowen, R. L., and R. A. Young, 1985, "Financial and Economic Irrigation Benefit Function for Egypt's Northern Delta," Water Resources Research, Vol. 21 (8) : 1329-1335.

Burt, O. R., 1964, "Allocation of Capital Costs in Enterprise Budget," In Costs and Returns for Agricultural Commodities: Advances in Concepts Measurement, edited by M. C. Ahearn and U. Vasavada. Boulder, CO: West View Press : 259-272.

Chaudhry, M. A., and R. A. Young, 1989, "Valuing Irrigation Water in Punjab Province, Pakistan: A Linear Programming Approach,” Water Resource Bulletin, Vo1. 25 (5) : 1055-1061.

Debertin, D. L, 1986, Agricultural Production Economics, New York: Macmillan : 162.

Government of Pakistan, 2006, The Year Book of Agricultural Statistics, Islamabad: Ministry of Food, Agriculture and Livestock.

Government of Punjab, 2005, Pakistan: Punjab Economic Report: Towards a Medium-Term Development Strategy, Report N0.29373-PAK.

Heady, E. O., 1952, Economics of Agricultural Production and Resource Use, Englewood Cliffs, NJ: Prentice Hall : 407-408.

Poste1. 1999, Pillars of Sand: Can the Irrigation Miracle Last? Norton: New York, USA.

Young, R. A., 1985, "Input Models, Economic Surplus and the Evaluation of State or Regional Water Plans," Water Resource Research, Vo1. 21 (12): 1819-1823.

Young, R. A., 1995, Efficiency and Equity Consideration in Pricing and Allocating Irrigation Water, Policy Research Workshop : 1460, World Bank, Washington, DC. 
Appendix: LP Matrix for Large Farms on Mithaluck Distributary, Sargodha

\begin{tabular}{|c|c|c|c|c|c|c|c|c|c|c|c|c|c|c|}
\hline \multicolumn{3}{|c|}{ Activity Cotton Wheat } & $\begin{array}{l}\mathrm{K} . \\
\text { Fodder }\end{array}$ & \multicolumn{2}{|c|}{ Sugarcane } & \multirow{2}{*}{$\begin{array}{c}\begin{array}{c}\mathbf{R} . \\
\text { Fodder }\end{array} \\
12433\end{array}$} & \multicolumn{2}{|c|}{ Rice } & Maize & Citrus & \multicolumn{3}{|c|}{$\begin{array}{l}\text { Wheat+ Berseem } \\
\text { Citrus +Citrus }\end{array}$} & RHS \\
\hline Obj.(Rs) & 19805 & 10846 & 63848 & & 217 & & & 6625 & 12084 & 3800 & & 39500 & 36500 & \\
\hline \multicolumn{15}{|c|}{ Land (Acres) } \\
\hline Kharif & 1 & & 1 & & 1 & & & 1 & 1 & 1 & & 1 & 1 & $\leq 32$ \\
\hline Rabi & & 1 & & & 1 & 1 & & & & 1 & & 1 & 1 & $\leq 32$ \\
\hline \multicolumn{15}{|c|}{ Labor (Person-Days) } \\
\hline Jan & & 0.64 & & & .72 & 9.37 & & & 4.94 & 5.31 & & 5.85 & 15.62 & $\leq 150$ \\
\hline Feb & & 0.54 & & & 3.86 & 9.37 & & & 4.92 & 5.31 & & 8.83 & 15.25 & $\leq 150$ \\
\hline March & & 0.59 & & & .79 & 9.37 & & & 5.48 & 8.24 & & 14.45 & 20.15 & $\leq 150$ \\
\hline April & & 4.0 & 3.18 & & .79 & 11.25 & & & 0.79 & 10.4 & & & 14.00 & $\leq 150$ \\
\hline May & & & 0.79 & & .79 & 0.79 & & & & & & & & $\leq 150$ \\
\hline June & 1.84 & & 5.31 & & .3 & & & 3.3 & 3.3 & 3.3 & & & & $\leq 150$ \\
\hline July & 2.30 & & 5.31 & & .79 & & & .79 & 0.79 & 0.79 & & & & $\leq 150$ \\
\hline August & 3.23 & & 3.18 & & .07 & & & 079 & 079 & 0.79 & & & & $\leq 150$ \\
\hline Sept & 4.61 & & & & .79 & & & 2.30 & 2.30 & 2.31 & & 8.66 & & $\leq 150$ \\
\hline Oct & & & & & 39 & 1.5 & & 3.5 & 2.41 & 2.41 & & 12.92 & & $\leq 150$ \\
\hline Nov & & 2.19 & & & .79 & 6.25 & & .93 & 3.23 & 5.42 & & 5.16 & & $\leq 150$ \\
\hline Dec & & 0.54 & & & .79 & 7.5 & & & 4.92 & 4.63 & & 6.24 & 15.00 & $\leq 150$ \\
\hline \multicolumn{15}{|c|}{ Water (Acre-Inches) } \\
\hline Jan & & 2.82 & & & 32 & 7.61 & & & 4.23 & 2.3 & & 2.3 & 2.0 & $\leq 62.67$ \\
\hline Feb & & 2.82 & & & .86 & 4.57 & & & 2.51 & 3.5 & & 3.5 & 3.5 & $\leq 76.99$ \\
\hline March & & 2.82 & & & .46 & 1.53 & & & 0.85 & 2.0 & & 2.0 & 2.0 & $\leq 102.64$ \\
\hline April & & 0.94 & & & .46 & & & & & 1.5 & & 1.5 & 1.5 & $\leq 102,64$ \\
\hline May & & & 2.41 & & .46 & & & & & 4.0 & & 4.0 & 4.0 & $\leq 102.46$ \\
\hline June & 2.78 & & 2.41 & & .15 & & & & & 4.0 & & 4.0 & 4.0 & $\leq 128.34$ \\
\hline July & 2.78 & & 2.41 & & .63 & & & & & 5.0 & & 2.3 & & $\leq 128.34$ \\
\hline August & 2.78 & & 1.2 & & .63 & & & & & 5.0 & & 3.5 & & $\leq 102.64$ \\
\hline Sept & 2.78 & & & & .63 & & & & 5.07 & 4.0 & & 3.0 & & $\leq 129.23$ \\
\hline Oct & & & & & .63 & 9.11 & & & 5.07 & 3.0 & & 3.5 & 4.0 & $\leq 98.01$ \\
\hline Nov & & 3.29 & & & .86 & 9.11 & & & & 4.0 & & 4.0 & 4.0 & $\leq 80.44$ \\
\hline Dec & & 2.82 & & & .54 & 9.11 & & & & 5.0 & & 4.0 & 4.0 & $\leq 57.74$ \\
\hline $\mathrm{N}(\mathrm{NKg})$ & 21.62 & 22.77 & & & .99 & 11.50 & & 2.0 & 23 & 56 & & 36 & 31 & $\leq 1000$ \\
\hline $\mathrm{P}(\mathrm{NKg})$ & 32.37 & 20.64 & 0.0 & & .98 & 10.33 & & 2.00 & 17 & 45 & & 49 & 45 & $\leq 500$ \\
\hline \multicolumn{15}{|c|}{ Continued Appendix I } \\
\hline Buy & $\mathbf{J a}$ & in Feb & March & April & May & June J & uly & Aug & Sept & Oct 1 & Nov & Dec & $\mathbf{N}$ & $\mathbf{W}$ \\
\hline Labor $(\mathrm{R}$ & (s) & 090 & 90 & 90 & 90 & 110 & 110 & 90 & 90 & 90 & 90 & 90 & & \\
\hline $\begin{array}{l}\text { Fertilizer } \\
\text { (Rs./NKg }\end{array}$ & r & - & - & - & - & - & - & - & - & - & - & - & 19.304 & 45.32 \\
\hline $\begin{array}{l}\text { Water } \\
\text { Rs/Acre } \\
\text { Inch) }\end{array}$ & - & - & - & - & - & - & - & - & - & - & - & - & - & $\begin{array}{l}-\quad 100 \\
-10\end{array}$ \\
\hline
\end{tabular}

